\section{Tungvekter i palliativ medisin}

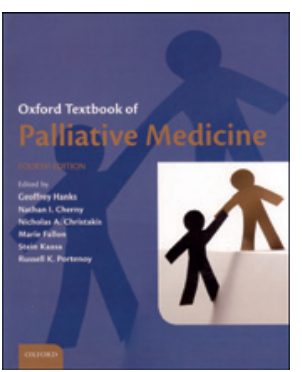

Geoffrey Hanks, Nathan I. Cherny, Nicholas A. Christakis et al, red. Oxford textbook of palliative medicine 4. utg. 1666 s, tab, ill. Oxford: Oxford University Press, 2011. GBP 80 ISBN 978-0-19-969314-6

Dette er fjerde utgave av standardverket i palliativ medisin. Helt siden første utgave i 1993 har Oxford textbook of palliative medicine (gjerne kalt OPM) vært referanseverket innen fagfeltet (1). Utviklingen i disse årene gjenspeiles også i størrelsen. Første utgave var på 845 sider, mens sidetallet i denne utgaven er doblet. Det samme er antall redaktører, og sett med norske øyne er det gledelig at onkologen Stein Kaasa i Trondheim er med som en av de seks redaktørene. De øvrige fem kommer fra Storbritannia, USA og Israel.

Boken er inndelt i 20 seksjoner, som igjen er delt i over 100 kapitler med mer enn 200 forfattere. Blant disse finner vi også flere norske. Jon Håvard Loge og Stein Kaasa skriver om livskvalitet, Dagny Faksvåg Haugen er med på et kapittel om organisering i team, og Lars Johan Materstvedt er medforfatter av kapitlet om eutanasi og legeassistert selvmord. Det er en fin anerkjennelse av gode norske fagmiljøer som er dyrket frem i de siste årene. Palliativ medisin er blitt et sterkt fagfelt i Norge, takket være en gruppe ildsjeler. Dette har manifestert seg på mange vis, ikke minst gjennom en serie viktige utgivelser, bl.a. en temaserie om palliativ medisin i Tidsskriftet (2) og en nordisk lærebok som hittil er kommet i to utgaver (3).

Innholdsfortegnelse og et detaljert og oversiktlig stikkordregister på over 40 sider gjør boken lett å finne frem i. Alle kapitler har fyldig referanseliste, teksten er ryddig inndelt med mellomtitler i blå skrift, og det er en fin veksling mellom tekst, tabeller og figurer.

Én seksjon handler om palliativ medisin ved ikke-malign sykdom. Ettersom tre firedeler dør av andre årsaker enn kreft, hadde jeg kanskje forventet at det var lagt større vekt på dette. På den annen side er det egne seksjoner om bl.a. pediatri og geriatri. Det er i det hele tatt en imponerende bredde i stofftilfanget, som dekker både kommunikasjon, etikk, forskning, utdanning og spesialisering og komplementær medisin, for bare å nevne noe. Alt stoff krever naturlig nok sin plass, og brevvekten min viser at boken nå veier i overkant av $4 \mathrm{~kg}$. Det er mye, antakelig for mye, for en paperbackutgave.

Det er neppe tvil om at denne nye utgaven befester sin posisjon som standardverket innen palliativ medisin.

\section{Erlend Hem \\ Tidsskriftet}

\section{Litteratur}

1. Haugen DF. Standardverket i palliativ medisin. Anmeldelse av: Doyle D, Hanks G, Cherny N et al, red. Oxford textbook of palliative medicine. Tidsskr Nor Lægeforen $2006 ; 126: 645$

2. Hem E, red. Palliativ medisin. Tidsskriftets skriftserie. Oslo: Tidsskrift for Den norske legeforening, 2006.

3. Fevang P. En god bok om det gamle temaet lindre og trøste. Anmeldelse av: Kaasa S, red. Palliasjon: nordisk lærebok. Tidsskr Nor Legeforen 2008; 128 1084.

\section{Et nyttig verktøy i kampen mot smerte?}

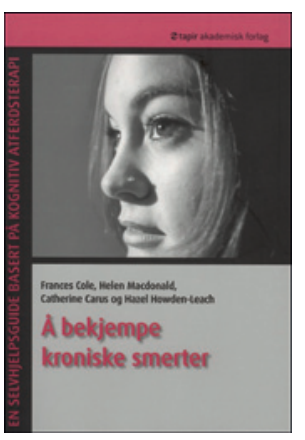

Frances Cole, Helen Macdonald, Catherine Carus et al.

\section{Å bekjempe kroniske smerter}

En selvhjelpsguide basert på kognitiv atferdsterapi. 269 s, tab, ill. Trondheim:

Tapir Akademisk Forlag, 2011. Pris NOK 245 ISBN 978-82-519-2715-4

Fire helsearbeidere, hvorav en kognitiv atferdsterapeut, en lege og en fysioterapeut, har gått sammen og skrevet en selvhjelpsguide, basert på kognitiv atferdsterapi, for pasienter som slåss mot langvarige smerter. Dette er en praktisk og detaljrik oppskriftsbok som vil kunne være til hjelp for smertepasienter med vilje til å strekke seg videre. Den kan også være nyttig for helsepersonell som er engasjert i mestringsrettet undervisning eller behandling av pasienter med langvarige smerter. I innledningen får leseren en kort oversikt over mekanismene ved langvarig smerte og kognitiv atferdsterapi, i tillegg til en veiledning i hvordan man kan bruke boken.

Del 1 heter Hva er kroniske smerter. Forfatterne gir en forbilledlig innføring i kompliserte smertemekanismer som personer uten medisinsk bakgrunn kan forstå. Når de innfører begreper som «A-nerver» (for akutte smerter) og «K-nerver» (for kroniske smerter), beveger de seg derimot over i det metaforiske.

Kronisk smerte utgjør definitivt et alvorlig helseproblem, og prevalenstallene for Norge er høyere enn $10 \%$, sannsynligvis et sted mellom 25-30\%. Kapitlene hvor forfatterne presenterer helsevesenets rolle og medikamenters plass i behandlingen, er ikke godt nok oppdatert eller systematisert. Det kan forvirre pasienter når man omtaler medikamenter som ikke er tilgjengelige, eller når man bruker medikamentnavn som ikke finnes i de norske listene. Man burde konsekvent valgt generiske medikamentnavn.

Del 2, Å bekjempe kroniske smerter, inneholder egne kapitler for viktige arenaer som belønning, riktig aktivitetsnivå, søvn, smerter, kommunikasjon, det sosiale, mestring av depresjon, angst, sinne og aksept - kapitler som fortjener grundig gjennomlesning.

Forfatterne bruker nyttige pasienteksempler som går igjen i flere kapitler. De presenterer sjekklister og tabeller i god kognitiv terapitradisjon. På slutten har de lagt inn en kort ordliste med medisinske uttrykk og tegninger over kroppsøvelser og hensiktsmessige kroppsstillinger ved f.eks. samleie. Verdien av disse kan jeg vanskelig vurdere.

Boken har et velegnet format med paperbackinnbinding, og forsiden er troverdig og innbyr til tillit. Oversettelsen bærer derimot preg av hastverk og ville ha tjent på råd fra medisinskfaglig ekspertise. Det er trist fordi denne typen bok har et viktig potensial og hadde derfor fortjent en mer optimal oversettelse og tilrettelegging for norske forhold - som pasienten møter. Like fullt, jeg anbefaler boken, men den vil, for de fleste pasientene, ha størst verdi som ledd $i$ en veiledet terapi.

\section{Gunnvald Kvarstein}

Smerteseksjonen

Oslo universitetssykehus, Rikshospitalet 